\title{
CONTINUOUS DIFFUSION OF AUSTRIAN MODEL GERMAN FRONT VOWELS: A SOCIOLINGUISTIC ANALYSIS
}

\author{
S.Ramanuj \\ Department Of Philology, University Of Colombo, Shri Lanka
}

\section{ABSTRACT}

In Austrian Model German ASG, the vowels in the words Beeren and Bärenare ordinarily respected to be consolidated. Some acoustic investigations on ASG additionally recommend a consolidation between the vowels as in Maitland Mitteand even between the BEEREN/BÄREN consolidation and the MIETE vowel. This paper re-examines these consolidations from a sociolinguistic perspective and shows that more established speakers will in general union the vowels more than more youthful speakers. This focuses towards a continuous scattering or 'unmerger' and we contend that this is an aftereffect of convenience toward Model German as it is articulated in Germany.

KEYWORDS:- Austrian ModelGerman, consolidation/'unmerger', vowel span

\section{INTRODUCTION}

German has been portrayed as a pluricentric language with three obviously particular public assortments (specifically, ModelGerman, Austrian ModelGerman, and Swiss ModelGerman see likewise Clyne (1991); Ammon (1995); Ammon (1996)). The current article centers around the Austrian assortment of ModelGerman ASG, which varies from ModelGerman as spoken in Germany "Northern ModelGerman" at the lexical, down to earth, and linguistic level, just as in pronunciation.1Here we concentrate on the way to express the non-low front unrounded vowels, which show an intriguing example of previous consolidation and current inversion. We will show that, beforehand, four vowels, in particular/:/, were incompletely blended, however that they are right now going through inversion. In the rest of this paper, we allude to these sounds as the MIETE, MITTE, BEEREN, and BÄREN vowels separately, adjust the conventional articulation in these words in NSG: Miete 'lease', Mitte 'center', Beeren 'berry.PLUR', and Bären 'bear.PLUR'(cf. the Duden Pronunciation Dictionary Mangold 1994.

\section{Discussion}

Previous examinations detailed variable balance of the MIETE and MITTE vowels and the BEEREN/BÄREN merger in ASG. As per concentrates on logical etymology on ASG Muhr, 
CURRENT RESEARCH JOURNAL OF PHILOLOGICAL SCIENCES 2(5): 18-19,

May 2021 DOI: https://doi.org/10.37547/philological-crjps-02-05-05

ISSN 2767-3758

(C)2021 Master Journals

Crossref dof 81 Google

Accepted2 ${ }^{\text {th }}$ May, 2021 \& Published 28 $8^{\text {th }}$ May, 2021

1995; Muhr, 2003 and elocution concentrates on Swiss Model German Hove, 2002, Sloos, To show up , we speculated that ASG vowels are dependent upon convenience to NSG. We consequently examined the level of differentiation between these vowels in unconstrained discourse, and analyzed the way to express more youthful and more seasoned speakers. We tracked down that the more youthful speakers produce more differentiation between the vowels than more seasoned speakers. Also, we showed that more youthful speakers misuse the vowel space more than more seasoned speakers, indicating that the vowels are dependent upon continuous scattering.

\section{Conclusion}

In Austrian ModelGerman, the four unrounded front vowels are dependent upon progressing scattering. We characteristic this example of progress to language contact with ModelGerman, the unmistakable esteem assortment, and ensuing convenience of more youthful speakers. More established speakers, kept a generally limited utilization of the vowel space and a consolidation of the BEEREN/BÄRENvowel pair and the MIETE/MITTEvowel pair.
Varietäten[The German language in Germany, Austria and Switzerland: The issue of public varieties].

3. Andersen, Margaret, and Taylor.. (1997). On contrasting the focuses of plurinational dialects: The case of German. In Contributions to the Sociology of Language, M. Hellinger and U. Ammon, Eds. 17-36. Berlin: Walter de Gruyter.

4. Stearns, M. J., \& Voge, W. (2011). Praat: Doing phonetics by PC. (PC program).

5. Traunmüller, H. (2007). German today: An areally broad corpus of spoken model German. In Proceedings of the Sixth International Conference on Language Resources and Evaluation (Marrakech, Marocco). 3185-3192.

6. Wiesinger, P. (1992). German as a pluricentric language. In Pluricentral Languages. Varying Norms in Different Nations, M. Clyne, Ed.117-147. Mouton de Gruyter, Berlin.

\section{REFERENCES}

1. Howard .(1972). Das Vokalsystem der Mundart des Monitions[The vowel arrangement of the vernacular of the Montafon]. Zeitschrift Für Dialektologie Und Linguistik. 38,1, 95-121.

2. Ammon, U. (1996). Pass on deutsche sprache in Deutschland, Österreich und der Schweiz: Das Problem der nationalen 